\title{
'SpineCor' apical vertebral rotation measuring tool
}

\author{
Alison Murray ${ }^{*}$, Tim Cook \\ From 10th International Conference on Conservative Management of Spinal Deformities - SOSORT 2013 \\ Annual Meeting \\ Chicago, IL, USA. 8-11 May 2013
}

\section{Background}

The measurement of Apical Vertebral Rotation (AVR) is vital to the surgical and conservative treatment of idiopathic scoliosis. Several measuring methods are used to assess the AVR on plain radiographs, including the visual Nash and Moe, Perdriolle's torsion meter and Raimondi's table, all of which have positive and negative aspects [1-3].

\section{Purpose}

We developed an AVR image scale of $0-55^{\circ}$ rotation, predetermined, to assess its ease of use as a visual method when comparing the mean inter-and intra-reliability against Perdriolle's and Raimondi's scales.

\section{Method}

A human lumbar vertebra (L4) set on a rotating device, and a series of $\mathrm{X}$ rays were taken, at 1 degree increments, from $0-55^{\circ}$ clockwise rotation. These images were flipped to produce $0-55^{\circ}$ counterclockwise rotation. The apical rotations of 39 curves was measured by three different observers (each having more than three years of experience specializing in the field of scoliosis) using the SpineCor AVR scale, Perdriolle's torsion meter and Raimondi's table. The measurements were taken twice, with a minimum of one week between each measurement.

\section{Results}

The inter-rater mean difference for the SpineCor AVR scale versus both Perdriolle's and Raimondi's was the same (within $0.01^{\circ}$ ) but this mean difference was greater than the mean difference between Raimondi's and Perdriolle's by $0.48^{\circ}$ and $0.49^{\circ}$ respectively (SpineCor AVR scale versus Raimondi $=$ mean difference of $4.18^{\circ} \mathrm{SD}+/-2.04^{\circ}$, SpineCor AVR scale $v$ Perdriolle's $=$ mean difference $4.19^{\circ} \mathrm{SD}+/-$ $2.05^{\circ}$, Raimondi's v Perdriolle's $\left.=3.70^{\circ} \mathrm{SD}+/-1.92^{\circ}\right)$; the intra-rater mean difference was $1.07^{\circ}$ greater with the

\footnotetext{
* Correspondence: A.Murray@spinecor.com
}

SpineCorporation Ltd, Montreal, QC, Canada
SpineCor AVR scales than with Perdriolle's and $0.45^{\circ}$ greater than Raimondi's table (intra-rater mean difference for the three testers with SpineCor images $=2.29^{\circ} \mathrm{SD}+/-$ $0.44^{\circ}$, with Raimondi's $=1.84^{\circ} \mathrm{SD}+/-0.39^{\circ}$ and with Perdriolle's $=1.22^{\circ} \mathrm{SD}+/-0.44^{\circ}$ ).

\section{Conclusions and discussion}

The SpineCor AVR scales demonstrated high intra-reliability mean differences with a mean difference of $2.29^{\circ}$ $\mathrm{SD}+/-0.44^{\circ}$ and inter-reliability of $4.18^{\circ}+/-2.04^{\circ} \mathrm{SD}$ and $4.19^{\circ}+/-2.05^{\circ} \mathrm{SD}$, which does appear to demonstrate favourable intra- and inter-reliability in comparison to both Perdriolle's and Raimondi's scales[1,2].

Published: 18 September 2013

\section{References}

1. Omeroglu $\mathrm{H}$, Ozekin $\mathrm{O}$, Bicimoglu A: 'A measurement of vertebral rotation in idiopathic scoliosis using the Perdriolle torsionmeter: a clinical study on intra-observer and inter-observer error'. Eur. Spine J 1996, 5(3):167-171.

2. Lam GC, et al: 'Vertebral rotation measurement: a summary and comparison of common radiographic and CT methods'. Scoliosis 2008, 3:16.

3. Weiss HR: 'Measurement of vertebral rotation: Perdriolle versus Raimondi'. Eur Spine J 1995, 4(1):34-38.

doi:10.1186/1748-7161-8-S2-O19

Cite this article as: Murray and Cook: 'SpineCor' apical vertebral rotation measuring tool. Scoliosis 2013 8(Suppl 2):O19.

Submit your next manuscript to BioMed Central and take full advantage of:

- Convenient online submission

- Thorough peer review

- No space constraints or color figure charges

- Immediate publication on acceptance

- Inclusion in PubMed, CAS, Scopus and Google Scholar

- Research which is freely available for redistribution

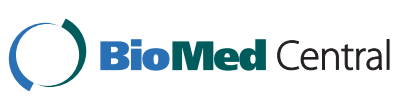

(c) 2013 Murray and Cook; licensee BioMed Central Ltd. This is an Open Access article distributed under the terms of the Creative Commons Attribution License (http://creativecommons.org/licenses/by/2.0), which permits unrestricted use, distribution, and reproduction in any medium, provided the original work is properly cited. 